\title{
Metabotropic Glutamate Receptor Subtype 7 Ablation Causes Dysregulation of the HPA Axis and Increases Hippocampal BDNF Protein Levels: Implications for Stress-Related Psychiatric Disorders
}

\author{
Kayo Mitsukawa', Cedric Mombereau', Erika Lötscher', Doncho P Uzunov', Herman van der Putten', \\ Peter J Flor*,' and John F Cryan' \\ 'Neuroscience Research, Novartis Institutes for BioMedical Research, Novartis Pharma AG, Basel, Switzerland
}

Regulation of neurotransmission via group-III metabotropic glutamate receptors (mGluR4, -6, -7, and -8) has recently been implicated in the pathophysiology of affective disorders, such as major depression and anxiety. For instance, mice with a targeted deletion of the gene for mGluR7 ( $\mathrm{mGluR} 7^{-1-}$ ) showed antidepressant and anxiolytic-like effects in a variety of stress-related paradigms, including the forced swim stress and the stress-induced hyperthermia tests. Deletion of mGluR7 reduces also amygdala- and hippocampus-dependent conditioned fear and aversion responses. Since the hypothalamic-pituitary-adrenal (HPA) axis regulates the stress response we investigate whether parameters of the HPA axis at the levels of selected mRNA transcripts and endocrine hormones are altered in mGluR7-deficient mice. Over all, mGluR7 ${ }^{-1-}$ mice showed only moderately lower serum levels of corticosterone and ACTH compared with $m G l u R 7^{+/+}$mice. More strikingly however, we found strong evidence for upregulated glucocorticoid receptor (GR)-dependent feedback suppression of the HPA axis in mice with mGluR7 deficiency: (i) mRNA transcripts of GR were significantly upregulated in the hippocampus of mGluR7 ${ }^{-1-}$ animals, (ii) similar increases were seen with 5-HT IA receptor transcripts, which are thought to be directly controlled by the transcription factor GR and finally (iii) $m G l u R 7^{-1-}$ mice showed elevated sensitivity to dexamethasone-induced suppression of serum corticosterone when compared with $\mathrm{mGluR7^{+1+ }}$ animals. These results indicate that $\mathrm{mGluR7}$ deficiency causes dysregulation of HPA axis parameters, which may account, at least in part, for the phenotype of $\mathrm{mGluR7}^{-1-}$ mice in animal models for anxiety and depression. In addition, we present evidence that protein levels of brain-derived neurotrophic factor are also elevated in the hippocampus of $m G l u R 7^{-1-}$ mice, which we discuss in the context of the antidepressant-like phenotype found in those animals. We conclude that genetic ablation of mGluR7 in mice interferes at multiple sites in the neuronal circuitry and molecular pathways implicated in affective disorders.

Neuropsychopharmacology (2006) 3 I, I I |2- I | 22. doi: I 0. I038/sj.npp. I 300926; published online 12 October 2005

Keywords: glutamate; depression; anxiety; group-III mGluR; hypothalamic-pituitary-adrenal axis; 5-HTIA receptor

\section{INTRODUCTION}

Stress-related psychiatric disorders such as depression and anxiety disorders are an enormous public health concern (Wong and Licinio, 2001, 2004). Further, current treatments which largely target monoamine or GABAergic neurotransmission, are of limited efficacy in a significant proportion of patients and are associated with a troublesome side-effect

*Correspondence: Dr PJ Flor, Neuroscience Research, Novartis Institutes for BioMedical Research, Novartis Pharma AG, WKL125.6.08, Basel CH-4002, Switzerland, Tel: +4I 616964218 , Fax: +4I 6169 62809, E-mail: peter_josef.flor@novartis.com

Received 15 April 2005; revised 25 August 2005; accepted 30 August 2005

Online publication: 2 September 2005 at http://www.acnp.org/citations/ Npp090205050252/default.pdf burden in many others resulting in a huge need for the development of novel treatment strategies. Accumulating evidence suggests a role for glutamatergic systems and in particular metabotropic glutamate receptors (mGluRs) in the pathophysiology of stress-related behavioral disorders (Krystal et al, 2002; Paul and Skolnick, 2003; Bergink et al, 2004; Swanson et al, 2005). Using genetically modified mice we and others have recently implicated a role for group-III mGluR subtypes (including mGluR4, $-6,-7$, and -8) in anxiety and depression (Masugi et al, 1999; Linden et al, 2002; Cryan et al, 2003).

mGluR7, which is the most highly conserved of all mGluR subtypes across different mammalian species (Makoff et al, 1996; Flor et al, 1997), is abundant in brain regions that are known to be critical for the manifestation of anxiolysis and antidepressant action, such as the hippocampus, the 
amygdala, and the locus coeruleus (Kinoshita et al, 1998). Mice lacking mGluR7 have deficits in amygdala-dependent behaviors (fear response and conditioned taste aversion), but show no alterations in locomotor activity or pain sensitivity (Masugi et al, 1999). Electrophysiological analysis in mGluR7 $7^{-1-}$ mice further suggests that this receptor is a frequency-dependent regulator of neurotransmitter release (Sansig et al, 2001), and modulates short-term synaptic plasticity in the hippocampus (Bushell et al, 2002). Moreover, we have demonstrated that mGluR7 ablation in mice is associated with changes in animal behavioral paradigms predictive of antidepressant and anxiolytic action, which suggests that drugs acting at mGluR7 may provide novel treatments for psychiatric disorders such as depression and anxiety (Cryan et al, 2003). These tests, including the forced swim test, tail suspension test, lightdark box test, and the stress-induced hyperthermia test, all involve behaviorally observing the animal's response to a novel stressful situation. Hence our data suggest that mGluR7 may play a role in the integration of the stress response to aversive stimuli.

The hypothalamic-pituitary-adrenal (HPA) axis is the key regulator of the stress reaction. Dysregulation of this axis is thought to play a central role in the pathophysiology of anxiety and depressive disorders (Plotsky et al, 1998; Steckler et al, 1999; Holsboer, 2000; Posener et al, 2000; Lopez et al, 1998; De Kloet et al, 2005). During stress, the synthesis of corticotrophin-releasing factor (CRF) in the hypothalamic paraventricular nucleus (PVN) increases and when CRF is released and reaches the anterior pituitary gland, it promotes the release of adrenocorticotropic hormone (ACTH), which, in turn, induces the synthesis and release of glucocorticoids from the adrenal cortex. Two types of glucocorticoid receptors (GRs) are well known in brain; the mineralcorticoid receptor (MR) and the GR, the latter having less affinity to corticosterone than MR (De Kloet et al, 1998). During stress the main function of GR in the brain appears to suppress stressinduced hyperactivity of the HPA axis at the level of the PVN, the anterior pituitary, but also at the hippocampal level (reviewed in Jacobson and Sapolsky, 1991; Barden, 2004).

Furthermore, the serotonin (5-HT) system and the HPA axis have complex inter-relationships (Porter et al, 2004). In particular, the $5-\mathrm{HT}_{1 \mathrm{~A}}$ receptor $\left(5-\mathrm{HT}_{1 \mathrm{~A}} \mathrm{R}\right)$ is very susceptible to modulation by stress and HPA-axis activation and is well known to play an important role in the pathophysiology of mood disorders (Lopez et al, 1998; Cryan and Leonard, 2000; Leitch et al, 2003). Accumulating evidence points also to an important role for the neurotrophin brainderived neurotrophic factor (BDNF) in both the pathophysiology of mood disorders and in the therapeutic effects of antidepressants (Duman, 2002; Castren, 2004; Hashimoto et al, 2004). Further, hippocampal BDNF levels are modified by many types of chronic stress (Smith et al, 1995; Vaidya et al, 1997; MacQueen et al, 2003).

Given that $\mathrm{mGluR}^{-1-}$ mice have a phenotype that is indicative of an altered behavioral response to stress, we hypothesized that mGluR7 affects stress-related systems at different levels. Therefore, we used $\mathrm{mGluR7}^{-1-}$ mice and tested the effects on levels of stress-related genes and hormones, and also examined the effects on the negative feedback system of the HPA axis by using the dexamethasone suppression test. To further test the possibility that BDNF is involved in antidepressant and anxiolytic phenotype of mGluR7 ${ }^{-1-}$ mice, we investigated BDNF mRNA and protein levels. These studies reveal HPA-axis dysregulation in mGluR7 $^{-1-}$ mice, which may provide a physiological correlate for the behavioral phenotype of these mice.

\section{MATERIALS AND METHODS}

\section{Animals}

mGluR7 $^{-1-}$ mice were generated as described previously from E14 (129/Ola) embryonic stem cells (Sansig et al, 2001). Larger age-matched groups of $\mathrm{mGluR7}^{-1-}$ and mGluR7 $7^{+/+}$mice were generated using a specific pathogen-free (SPF) breeding colony of 30 F14, B6-mGluR7 ${ }^{+/-}$ males mating with $60-90$ F14, B6-mGluR7 ${ }^{+/}$females. All the mice in the studies reported here carried wild-type or mutant mGluR7 alleles on a 14th generation C57BL/6 genetic background. Mice were weaned at the age of 3 weeks, when tail biopsies were also taken for genotyping. Subsequently, genotyped mice were moved to a non-SPF conventional facility in which male animals were used for experiments at the ages of 3-9 month. Housing was at room temperature, in a $12 \mathrm{~h}$ light:dark cycle, with lights on at 0600. Male animals were used in all experiments. Food pellets and tap water were available ad libitum unless stated otherwise. Following decapitation of mice (mGluR7 ${ }^{-1-}$ and mGluR7 $7^{+1+}$ mice in a randomized order), bloods were collected and brains were immediately removed and frozen on dry ice and stored at $-80^{\circ} \mathrm{C}$. All animal experiments were subject to institutional review and conducted in accordance with the Veterinary Authority of Basel-Stadt, Switzerland.

\section{Blood Sample Collection for Basal and Stress-Induced Conditions}

In order to investigate the effects of $\mathrm{mGluR7}^{-1-}$ mice on basal corticosterone and ACTH levels, male mGluR7 ${ }^{-1-}$ $(n=10)$ and littermate mGluR7 $^{+1+}(n=10)$ mice were decapitated and the blood was collected. Two batches of mice were killed, one between 0700 and 0800 and the other between 1700 and 1730. For the stress-induced hormone levels, male $\mathrm{mGluR7}^{-1-}$ and littermate GGluR7 $^{+1+}$ mice were subjected to swim stress $(6 \mathrm{~min})$ into plexiglass cylinders $(24 \mathrm{~cm}$ tall $\times 21 \mathrm{~cm}$ in internal diameter $)$ filled with water $\left(23-25^{\circ} \mathrm{C}\right)$. Mice were decapitated 5 or $90 \mathrm{~min}$ after the stress session $(n=10$ per genotype and per time point) in another room and the blood was collected between 0800 and 1100. Simultaneously, nonstressed male mice ( $n=10$ per genotype) were killed, which constituted control groups.

\section{Blood Sample Collection following Dexamethasone Suppression Test}

The dexamethasone suppression test was carried out essentially as described by Groenink et al (2002). Male mGluR7 ${ }^{-I-}$ and littermate mGluR7 $7^{+1+}$ mice were injected subcutaneously (SC) with saline, 0.03 or $0.1 \mathrm{mg} / \mathrm{kg}$ dex- 
amethasone-21-phosphate disodium salt (Fluka, Buchs, Switzerland). After $6 \mathrm{~h}$, mice were decapitated rapidly (within $30 \mathrm{~s}$ after first touching the cage) in an adjacent room, and trunk blood was collected ( $n=10$ per genotype).

\section{Hormone Measurements}

Plasma corticosterone and ACTH concentrations were measured using commercially available radioimmunoassay kits (ICN Biomedicals, Costa Mesa, CA, USA). The interand intra-assay coefficients of variability for ACTH and corticosterone were similar to the manufacturer's reported values with a detection limit of $5-10 \mathrm{pg} / \mathrm{ml}$.

\section{Extraction of BDNF from Tissues}

Various brain regions were freshly dissected, weighed, collected on dry ice, and stored at $-80^{\circ} \mathrm{C}$, or dissected as soon as the frozen brains started to thaw as specified below. The extraction of BDNF was performed essentially as described previously (Kolbeck et al, 1999). Briefly, 20$40 \mathrm{vol} / \mathrm{wt}$ of extraction buffer $(0.05 \mathrm{M}$ sodium acetate, $\mathrm{pH}$ 4.0, $1.0 \mathrm{M}$ sodium chloride, $1 \%$ (vol/wt) BSA (A-9418 of Sigma, Buchs, Switzerland), 1\% Triton X-100, protease inhibitor cocktail tablets (Cat.No. 1836 153, Roche, Rotkreuz, Switzerland)) was added and the tissues sonicated to homogeneity. The homogenates were kept on ice for $1 \mathrm{~h}$ and the sonication repeated three times. The homogenates were centrifuged $\left(15 \mathrm{~min}, 10^{5} \mathrm{~g}\right)$, the supernatants (first extraction) collected, and the pellets resuspended in 20-40 volumes of extraction buffer. After another centrifugation $\left(15 \mathrm{~min}, 10^{5} \mathrm{~g}\right)$, the supernatants were collected (second extraction) and the pellets resuspended in 20-40 volumes of extraction buffer. After another centrifugation $\left(15 \mathrm{~min}, 10^{5} \mathrm{~g}\right)$, the supernatants were collected again (third extraction).

\section{BDNF Immunoassay}

Quantification of BDNF from tissue extracts was carried out essentially as described by Kolbeck et al (1999). Plates (MaxiSorp plates, Nunc, Rosklide, Denmark) were coated with carbonate buffer, $\mathrm{pH} 9.7$ containing $400 \mathrm{ng}$ per well of biotinylated first anti-BDNF antibody (courtesy of Y.-A. Barde, Basel University, Switzerland) overnight at $4^{\circ} \mathrm{C}$ and incubated with blocking buffer (phosphate-buffered saline, $2 \%$ BSA, $0.1 \%$ Triton $\mathrm{X}-100$ ) for $1 \mathrm{~h}$ at room temperature. Standard amounts of BDNF were diluted in extraction buffer $(0.1-6.25 \mathrm{ng} / \mathrm{ml})$, and $25 \mu \mathrm{l}$ per well of each concentration was applied. A measure of $25 \mu \mathrm{l}$ per well of the extraction buffer alone (negative control) was used to check background activity. Similarly, $25 \mu \mathrm{l}$ per well of different dilutions of the tissue-extract supernatants was added to the wells. Subsequently, $175 \mu \mathrm{l}$ per well of incubation buffer $(0.1 \mathrm{M}$ potassium/sodium phosphate, $\mathrm{pH} 8.0,1 \% \mathrm{BSA}$, protease inhibitor cocktail tablets (Cat.No. 1836 153, Roche, Rotkreuz, Switzerland)) containing $100 \mathrm{mU} / \mathrm{ml}$ peroxidase (POD)-conjugated anti-BDNF antibody (courtesy of Y.-A. Barde, Basel University, Switzerland) was applied and incubated overnight at $4{ }^{\circ} \mathrm{C}$. Plates were washed with washing buffer (phosphate-buffered saline, $0.1 \%$ Triton $\mathrm{X}-100)$ three times and incubated with $200 \mu \mathrm{l}$ per well of the BM blue POD substrate (Roche, Rotkreuz, Switzerland) for $30 \mathrm{~min}$ at room temperature. The reaction was stopped with $50 \mu \mathrm{l}$ of $1 \mathrm{M}$ sulfonic acid per well, and the intensity of the reaction product was measured in a luminometer at $490 \mathrm{~nm}$. BDNF levels in tissue extracts were determined by comparison with the standard curve.

\section{'Real-Time' Reverse Transcriptase (RT) PCR Assays}

Various brain regions were freshly dissected, weighed, collected on dry ice, and stored at $-80^{\circ} \mathrm{C}$, or dissected as soon as the frozen brains started to thaw. Mouse brain regions were disrupted $(2 \times 2 \mathrm{~min}$ at $20 \mathrm{~Hz})$ by using a Mixer Mill MM 300 (Retsch GmbH \& Co. KG, Haan, Germany). Total RNA was isolated from disrupted brain tissue using the commercially available 'Absolutely RNA $^{\text {TM }}$ RT-PCR Miniprep Kit (Stratagene, Amsterdam, The Netherlands). The quantity of RNA was determined by OD measurement using a NanoDrop ${ }^{\mathbb{R}}$ ND-1000 Spectrophotometer. To remove traces of genomic DNA contamination, an aliquot of $400 \mathrm{ng}$ total RNA was digested with RNAsefree DNAse I (RNAse-Free DNase Set, Qiagen, Hilden, Germany). The enzyme was inactivated by addition of EDTA and by heating up to $65^{\circ} \mathrm{C}$. DNAse I-treated total RNA was reverse transcribed into cDNA by random priming using StrataScript ${ }^{\mathrm{TM}}$ Reverse Transcriptase (Stratagene, Amsterdam, The Netherlands) at $42^{\circ} \mathrm{C}$ for $60 \mathrm{~min}$. Primers and probes were designed with the aid of the Primer Express software (Version 1.0; Applied Biosystems, Foster City, CA, USA). The probes were labeled at the $5^{\prime}$ end with the reporter fluorophore 6-carboxyfluorescein (FAM) and at the $3^{\prime}$ end with the quencher 6-carboxytetramethylrhodamine (TAMRA). Primers and probes were synthesized commercially (Microsynth, Balgach, Switzerland). The sequences of the primer pairs and probes were as shown in the table of sequences (below). 'Real-Time' RT PCR $\left(\right.$ TaqMan ${ }^{\mathbb{R}}$ ) assays were performed using the $\mathrm{qPCR}^{\mathrm{TM}}$ Mastermix (Eurogentec, Seraing, Belgium) on an ABI Prism ${ }^{\circledR} 7700$ sequence Detection System (Applied Biosystems, Foster City, CA, USA). In all assays for the target genes, primers and probes were used at 300 and $175 \mathrm{nM}$, respectively. Assays for the internal control gene 18S rRNA were performed by using the ' $18 \mathrm{~S}$ Genomic Endogenous Control Kit' (Eurogentec, Seraing, Belgium). Relative levels of the target mRNA are reported after normalization to $18 \mathrm{~S}$ rRNA, which was also detected by 'Real-Time' RT PCR. The normalized raw data, representing the average values of two independent determinations, were analyzed by using the comparative $C_{\mathrm{T}}$ method, as described in details by Livak and Schmittgen (2001).

\section{Statistical Analysis}

Relative gene and protein expression data are reported as means \pm SEM. Values of mGluR7 $^{-1-}$ mice were compared with those of mGluR7 $^{+/+}$mice by using the two-tailed Student's $t$-test. The level of significance was set at $p<0.05$.

\section{RESULTS}

\section{Analysis of Transcript Levels of Stress-Related Genes}

In an attempt to address the physiological basis of the behavioral phenotype of mGluR7 $7^{-1-}$ mice, which showed 
Table of Sequences: Primers and Probes Used in 'Real-Time' RT PCR Assays for Assessing Relative Expression Profiles of Target Genes

\begin{tabular}{|c|c|c|}
\hline $\begin{array}{l}\text { Gene } \\
\text { product }\end{array}$ & $\begin{array}{l}\text { GenBank/ } \\
\text { RefSeq } \\
\text { accession } \\
\text { number }\end{array}$ & Sequences of primer and probe \\
\hline BDNF & BC034862 & $\begin{array}{l}\text { 5'-CCA TAA GGA CGC GGA CTT GT-3' } \\
\text { 5'-GAG GCT CCA AAG GCA CTT GA-3' } \\
\text { 5'-FAM-CAC TTC CCG GGT GAT GCT CAG } \\
\text { CA-TAMRA-3' }\end{array}$ \\
\hline CRF & AYI 28673 & $\begin{array}{l}\text { 5'-AGC AGT TAG CTC AGC AAG CTC A-3' } \\
\text { 5'-GGC CAA GCG CAA CAT TTC-3' } \\
\text { 5'-FAM-TCC CGA TAA TCT CCA TCA GTT } \\
\text { TCC TGT TGC T-TAMRA-3' }\end{array}$ \\
\hline CRFI & $\times 27305$ & $\begin{array}{l}\text { 5'-TCC GGT GCC TGA GAA ACA TC-3' } \\
\text { 5'-CGT GGC GTT GCG TAG GA-3' } \\
\text { 5'-FAM-TCC ACT GGA ACC TCA TCT CGG } \\
\text { CTT TC-TAMRA-3' }\end{array}$ \\
\hline GR & $\times 04435$ & $\begin{array}{l}\text { 5'-CGG GAC CAC CTC CCA AA-3' } \\
\text { 5'-CCC CAT AAT GGC ATA CCG AA-3' } \\
\text { 5'-FAM-TCT GCC TGG TGT GCT CCG ATG } \\
\text { AAG-TAMRA-3' }\end{array}$ \\
\hline $5-\mathrm{HT}_{\text {IA }}$ & $\mathrm{NHOI} 2585$ & $\begin{array}{l}\text { 5'-GCT CAT GCT GGT TCT CTA CGG-3' } \\
\text { 5'-GAC AGT CTT GCG GAT TCG GA-3' } \\
\text { 5'-FAM- CGC ATC TTC AGA GCC GCA CGC- } \\
\text { TAMRA-3' }\end{array}$ \\
\hline mGluR7 & NM000844 & $\begin{array}{l}\text { 5'-GCG CTC GAA CAG TCG CTT A-3' } \\
\text { 5'-CGC ACG TCG GAG GTG TC-3' } \\
\text { 5'-FAM-TIT CGT CCA GGC GCT CAT CCA } \\
\text { GA-TAMRA-3' }\end{array}$ \\
\hline MR & XM356093 & $\begin{array}{l}\text { 5'-TGG ATG TGG TTG GAT GTA GGG-3' } \\
\text { 5'-TCT ACC TGT TGC AGC GCT TG-3' } \\
\text { 5'-FAM-CCA CGA CAA CCC TGC TGC GGA } \\
\text { G-TAMRA-3' }\end{array}$ \\
\hline
\end{tabular}

reduced anxiety- and depression-like features, we started with an analysis of gene expression levels associated with the stress system of the brain. The genes chosen were those encoding GR, MR, CRF, CRF1 receptor and the $5-\mathrm{HT}_{1 \mathrm{~A}} \mathrm{R}$. Figure 1 shows expression levels of mGluR7 and these five stress-related genes in the hippocampus, the hypothalamus and the prefrontal cortex of mGluR7 $7^{+1+}$ and $\mathrm{mGluR7}^{-1-}$ mice. As expected, there was no detectable level of mGluR7 mRNA either in the hippocampus, in the hypothalamus or in the prefrontal cortex of mGluR7 ${ }^{-1-}$ mice. In the hippocampus, mGluR7 ${ }^{-1-}$ mice showed an increased GR level compared to $\mathrm{mGluR7}^{+/+}$mice, which was highly significant in p.m. killed animals ( $p=0.007$; Figure 1d) but did not reach statistical significance in a.m. killed animals $\left(p=0.093\right.$; Figure 1a). $5-\mathrm{HT}_{1 \mathrm{~A}} \mathrm{R}$ levels were dramatically increased in the hippocampus and in the prefrontal cortex of both a.m. ( $p=0.002$ and 0.016 , respectively) and p.m. ( $p=0.002$ and 0.038 , respectively) killed $\mathrm{mGluR}^{-1-}$ mice, when compared to mGluR7 $7^{+/+}$mice (Figure 1a, c, d, f). The elevated levels of $5-\mathrm{HT}_{1 \mathrm{~A}} \mathrm{R}$ mRNA in the hypothalamus of mGluR7 ${ }^{-1-}$ mice did not quite reach the level of statistical significance ( $p=0.055$ and 0.064 ; for a.m. and p.m. killed animals respectively; Figure 1b, e). Expression levels of MR, CRF, and CRF receptor type 1 (CRFR1) remained unchanged in the hippocampus, the hypothalamus and the prefrontal cortex between the two genotypes. Interestingly, there was a trend towards a significant increase in CRFR1 $(p=0.076)$ and GR $(p=0.12)$ in the prefrontal cortex at the afternoon time point only.

\section{Basal Conditions of Stress Hormone Levels}

Basal levels of serum corticosterone and ACTH concentrations were measured in mGluR7 ${ }^{+/+}$and mGluR7 $^{-1-}$ mice; although $\mathrm{mGluR7}^{-1-}$ mice showed lower levels of both corticosterone and ACTH, especially in the morning (Figure 2), this did not reach statistical significance presumably due to the large variation between animals. Body weight and adrenal gland weight of GluR $^{-1-}$ mice were somewhat lower than those of $\mathrm{mGluR7}^{+/+}$mice; however adrenal gland weight normalized to body weight showed no difference between mGluR $7^{+/+}$and mGluR7 $7^{-I-}$ mice (Table 1). This was also the case in female mice (data not shown).

\section{Effects of Swim Stress on Stress Hormone Levels}

In a next experiment, we used mGluR7 $7^{+/+}$and $\mathrm{mGluR7}^{-1-}$ mice (10 male animals each) and tested the level of corticosterone and ACTH in response to swim stress. When blood samples were taken between 0800 and 1100, mGluR7 $^{-1-}$ mice showed remarkably lower levels of corticosterone (Figure 3a) and ACTH (Figure 3b) compared to mGluR7 $^{+9+}$ mice (corticosterone; 9.55 \pm 1.86 vs $27.57 \pm 6.86 \mathrm{ng} / \mathrm{ml}, p=0.029$, ACTH; $33.65 \pm 3.00 v s$ $75.55 \pm 18.78 \mathrm{ng} / \mathrm{ml}, p=0.054)$. These basal levels without swim stress showed less animal to animal variation than data of Figure 2. Immediately after swim stress, mGluR7 ${ }^{-1-}$ mice showed an increase in the levels of corticosterone (Figure 3c) and ACTH (Figure 3d) comparable to GluR7 $^{+1+}$ mice, and there was no difference between the two genotypes. In addition, $90 \mathrm{~min}$ after swim stress, the stressinduced increase of corticosterone and ACTH levels were recovered at least partially in both genotypes (Figure 3e, f), however interestingly the levels of both stress hormones in mGluR7 $7^{-1-}$ mice were lower than in mGluR7 $7^{+/+}$mice, which may lead to the suggestion that $\mathrm{mGluR}^{-1-}$ mice may affect the recovery of the hormonal system from the stress, although these differences did not reach statistical significance.

\section{Dexamethasone Suppression Test}

We also examined levels of plasma corticosterone and ACTH when mice were injected with the synthetic 

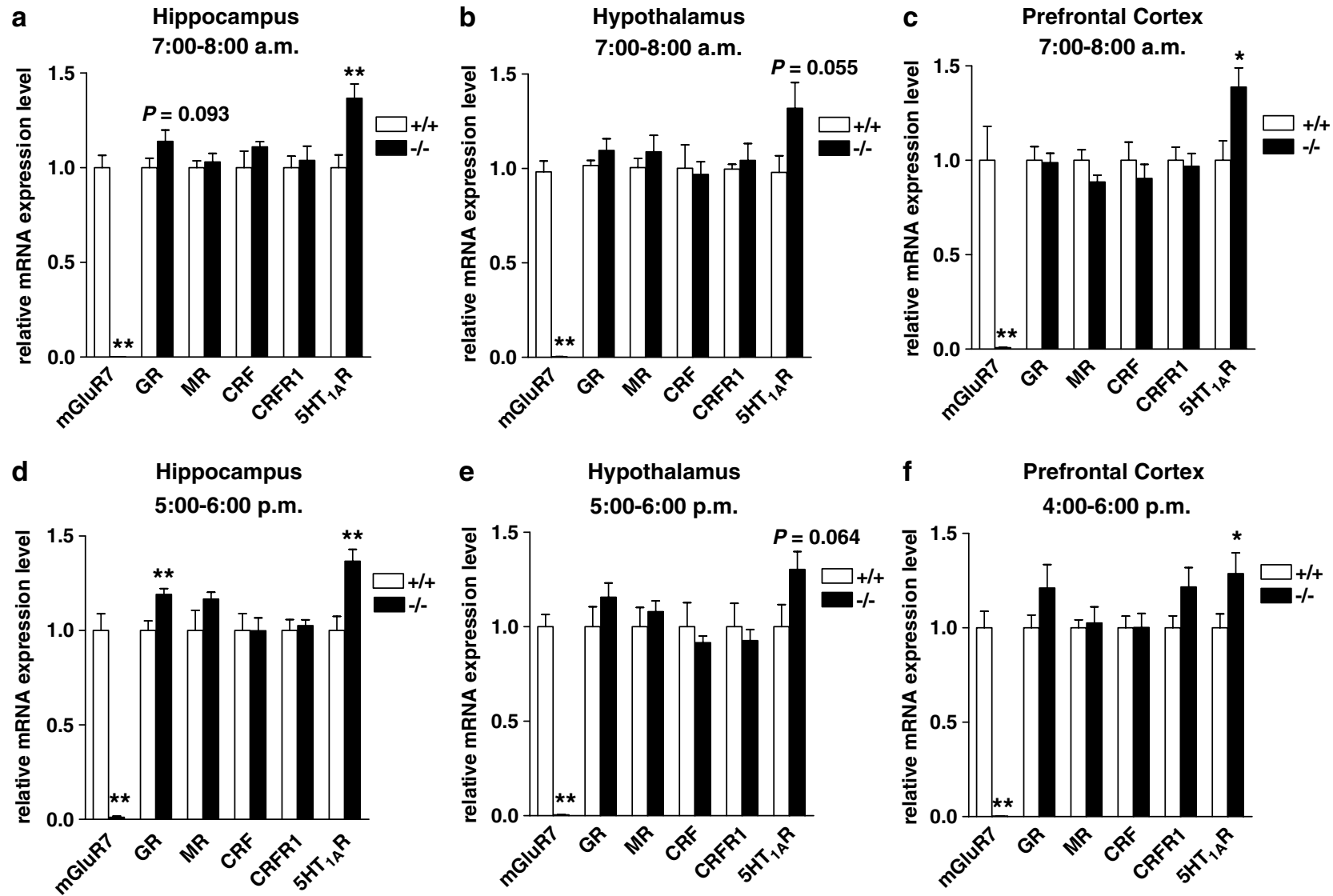

Figure I Relative transcript levels of mGluR7 and stress-related genes in the hippocampus ( $a$ and $d$ ), the hypothalamus (b and e) and the prefrontal cortex ( $\mathrm{c}$ and $\mathrm{f}$ ) of male $\mathrm{mGluR7} 7^{+/+}$and $\mathrm{mGluR} 7^{-1-}$ mice. Sample collection was performed in the morning $(0700-0800 ; \mathrm{a}-\mathrm{c})$ and in the afternoon ( $1600-$ I800; $d-f)$. All values are normalized to the expression level of the reference gene I8S rRNA. The mRNA levels of mGluR7 ${ }^{+/+}$mice are set arbitrarily to the expression level of 1.0. Expression levels in $\mathrm{mGluR7^{-1- }}$ mice (filled columns) are shown relative to $\mathrm{mGluR7}{ }^{+/+}$animals (opened columns). The data, displayed as means $\mathbf{S E M}$, are the average values of two independent determinations ( $a, b, d$, and e) or the average of triplicate determinations ( $c$ and $f$ ) Each bar represents a group of $7-12$ animals. Statistical analysis was carried out by Student's $t$-test. $* *$ $p<0.01$, * $p<0.05$; groups that differed significantly from mGluR7 ${ }^{+/+}$mice.

Table I Body Weight and Adrenal Gland Weight of Male mGluR7 $^{+/+}$and mGluR7 ${ }^{-1-}$ Mice

\begin{tabular}{lcccc}
\hline & & \multicolumn{2}{c}{ Andrenal gland weight } & \\
\cline { 3 - 4 } Genotype & Body weight $\mathbf{( g )}$ & $\mathbf{m g}$ & $\mathbf{m g / l 0} \mathbf{~ g ~ B W}$ & $\mathbf{n}$ \\
\hline$+/+$ & $30.3 \pm 0.6$ & $3.2 \pm 0.3$ & $1.0 \pm 0.1$ & 8 \\
$-/-$ & $26.6 \pm 1.1$ & $2.7 \pm 0.3$ & $1.0 \pm 0.1$ & 8 \\
\hline
\end{tabular}

BW, body weight.

Results represent means \pm SEM.

glucocorticoid, dexamethasone, to investigate the GRmediated negative feedback system of the HPA axis. Figure 4 illustrates plasma concentrations of corticosterone and ACTH in mGluR7 ${ }^{+1+}$ and mGluR7 $7^{-1-}$ mice injected with saline, 0.03 or $0.1 \mathrm{mg} / \mathrm{kg}$ dexamethasone subcutaneously (SC). Plasma corticosterone concentrations of vehicletreated $\mathrm{mGluR7}^{+/+}$and $\mathrm{mGluR7^{-1- }}$ mice were not different at afternoon time points (1400-1500; Figure $4 \mathrm{a})$ which is probably due to circadian pattern in the levels of circulating glucocorticoids. Therefore, this further illustrates that caution needs to be taken regarding the time of day that killing of animals is carried out for the assaying of stress hormones.

Administration of $0.03 \mathrm{mg} / \mathrm{kg}$ dexamethasone dramatically reduced plasma corticosterone level in mGluR7 ${ }^{-I-}$ mice (Figure 4c) and there was a significant difference between these two genotypes $(p=0.041)$. The injection of $0.1 \mathrm{mg} / \mathrm{kg}$ dexamethasone showed a remarkable suppression of corticosterone levels both in mGluR7 ${ }^{+/+}$and mGluR7 ${ }^{-1}$ mice (Figure 4e) compared to vehicle-treated animals of both genotypes (Figure $4 \mathrm{a}$ ) and there was no significant difference anymore between the two genotypes. On the other hand, at the same time points (1400-1500), the plasma ACTH level of vehicle-treated mGluR7 ${ }^{-1-}$ mice was significantly less than that of $\mathrm{mGluR} 7^{+/+}$mice (Figure $4 \mathrm{~b}$; $p=0.022$ ). Difference between ACTH levels and corticosterone levels may reflect the different temporal patterns of these stress hormones. Full online analysis of these hormones maybe required to discriminate these differences in detail. Administration of $0.03 \mathrm{mg} / \mathrm{kg}$ dexamethasone resulted in reduced plasma ACTH levels in mGluR7 $^{-1-}$ and mGluR7 ${ }^{+1+}$ mice (Figure $4 \mathrm{~d}$ ); ACTH was lower in mGluR7 ${ }^{-I-}$ mice than in mGluR7 ${ }^{+l+}$ mice, although this was not quite statistically significant $(p=0.061)$. With the injection of $0.1 \mathrm{mg} / \mathrm{kg}$ dexamethasone, both $\mathrm{mGluR}^{+/+}$ 

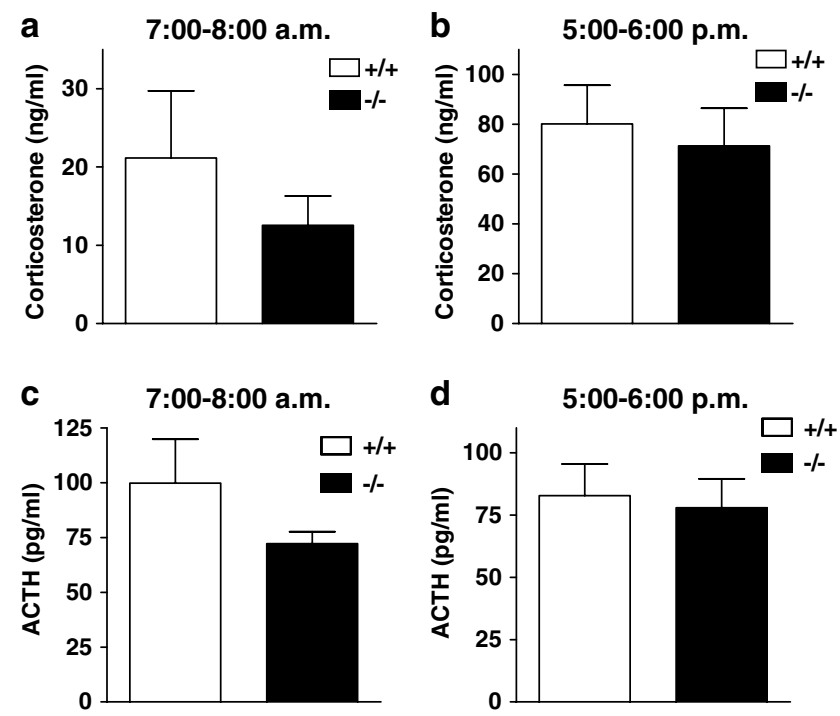

Figure 2 Basal plasma corticosterone ( $a$ and b) and ACTH ( $c$ and d) concentrations of male mGluR7 ${ }^{+/+}$and mGluR7 $^{-1-}$ mice $(n=8-10$ per group). Sample collection was performed in the morning (0700-0800; a and c) and in the afternoon (1700-1800; b and d). All bars represent means \pm SEM. Statistical analysis was done by Student's t-test. No mGluR7 ${ }^{-1-}$ group showed significant difference when compared with the $\mathrm{mGluR}^{+1+}$ group $(p>0.05)$.
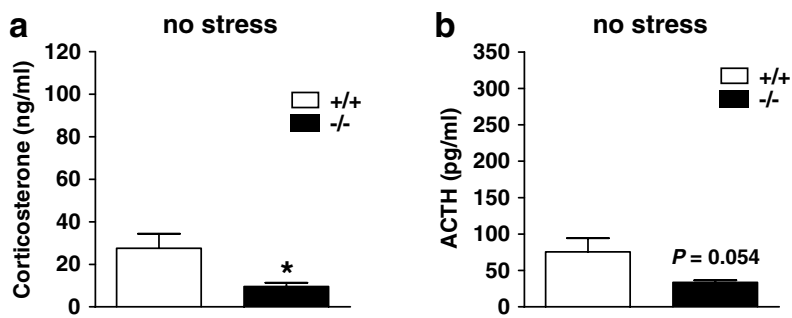

C immediately after stress
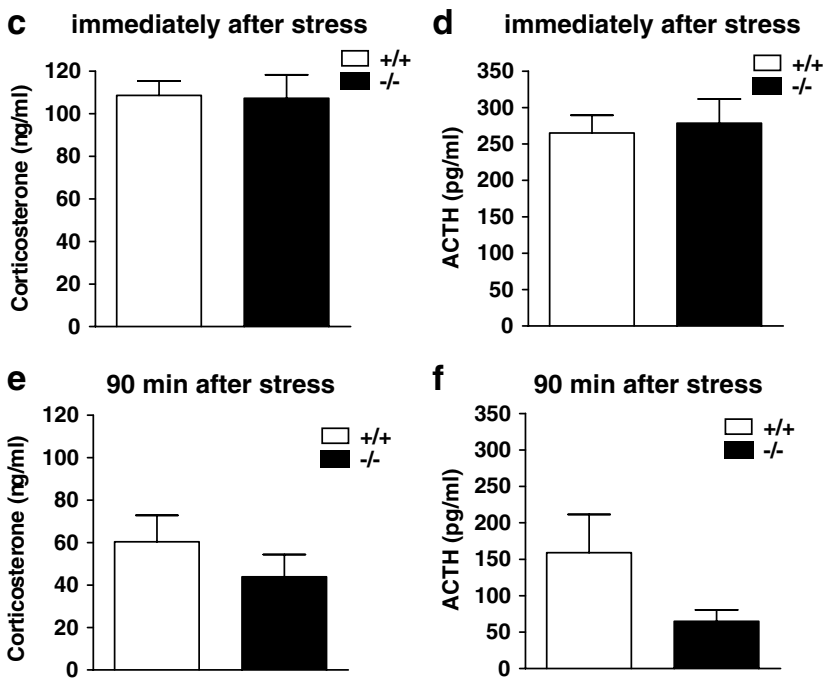

Figure 3 Baseline and swim-stress-modified levels of plasma corticosterone (a, c, and e) and $\mathrm{ACTH}$ (b, d, and $\mathrm{f}$ ) concentrations of male mGluR7 $^{+1+}$ and $\mathrm{mGluR7}^{-1-}$ mice ( $n=9-10$ per group). The duration of swim stress was 6 min. Sample collection was performed between 0800 and II00. All bars represent means \pm SEM. Statistical analysis was carried out by Student's $t$-test. $* 0<0.05$; groups that differed significantly from $m G l u R 7^{+/+}$mice.
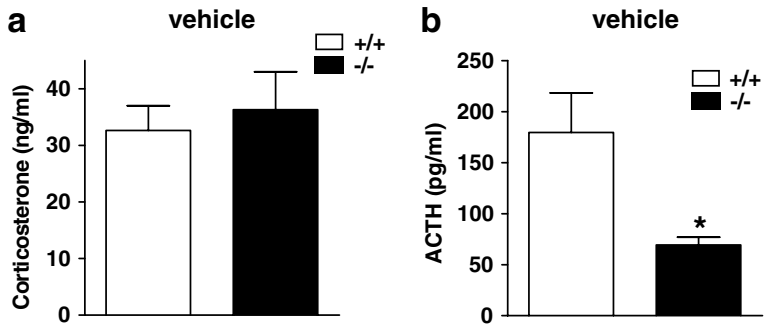

C $+0.03 \mathrm{mg} / \mathrm{kg}$ Dexamethasone
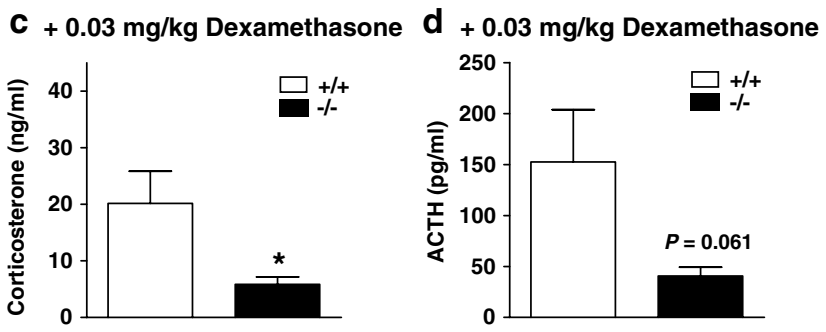

e $+0.1 \mathrm{mg} / \mathrm{kg}$ Dexamethasone

f $+0.1 \mathrm{mg} / \mathrm{kg}$ Dexamethasone
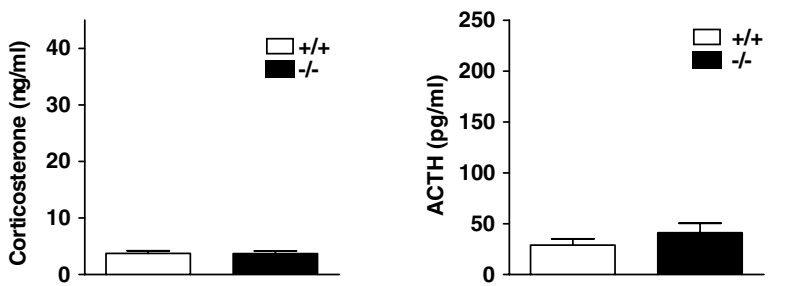

Figure 4 Baseline and dexamethasone-inhibited corticosterone ( $a, c$, and e) and ACTH (b, d, and f) concentrations of male mGluR7 ${ }^{+/+}$and mGluR7 ${ }^{-1-}$ mice ( $n=8-10$ per group). Sample collection was performed between 1400 and 1500, $6 \mathrm{~h}$ after subcutaneous (SC) injection of dexamethasone. All bars represent means \pm SEM. Statistical analysis was carried out by Student's $t$-test. ${ }^{*} p<0.05$; groups that differed significantly from mGluR7 $^{+1+}$ mice.

and mGluR7 $^{-1-}$ mice showed suppressed ACTH levels (Figure $4 \mathrm{f}$ ) and there was no significant difference between the genotypes.

\section{Expression Levels of BDNF Transcript and Protein}

Next, we investigated whether BDNF levels are changed in mGluR7 ${ }^{-1-}$ mice by using RT-PCR and ELISA assays for mRNA and protein level determination, respectively. Sample collection was in the afternoon (1600-1800). There was no significant difference in BDNF mRNA either in the hippocampus, in the hypothalamus, or in the prefrontal cortex between mGluR7 $7^{+/+}$and $\mathrm{mGluR7}^{-1-}$ mice (Figure 5a). However, mGluR7 ${ }^{-1-}$ mice showed a significantly increased level of BDNF protein in the hippocampus as compared to GluR7 $^{+/+}$mice $(p=0.022)$, although the prefrontal cortex showed no difference (Figure $5 b$ ) which demonstrates that there is a level of regional specificity to the increases in BDNF. We confirmed this result in the hippocampus by repeating the experiment independently with 9-12 mice per group in tissue that was freshly dissected (Figure 5c). We obtained the same differences between the two genotypes $(p=0.001)$, which demonstrates that mGluR7 ${ }^{-}{ }^{-}$mice show a $20-25 \%$ increase of BDNF protein level in the hippocampus as compared to $\operatorname{mGluR} 7^{+1+}$ animals. 


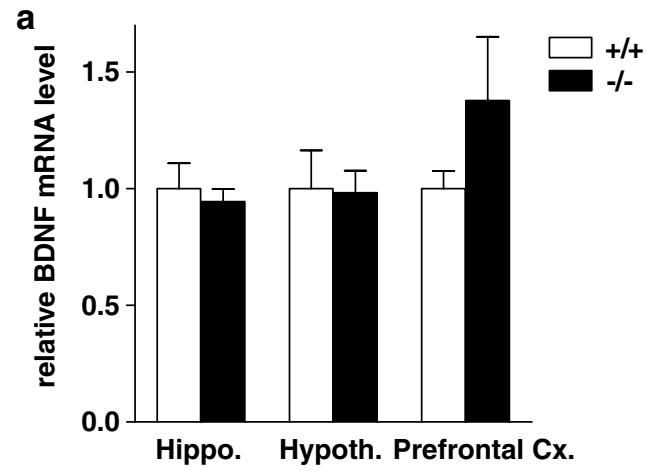

Thus, our findings suggest that drugs acting at mGluR7 may provide innovative and novel approaches to modify stress-related psychiatric disorders such as depression and anxiety.

mGluR7 ablation leads to increased levels of GR and the $5-\mathrm{HT}_{1 \mathrm{~A}} \mathrm{R}$ in the hippocampus without altering MR, CRF, or CRFR1 mRNA levels. 5- $\mathrm{HT}_{1 \mathrm{~A}} \mathrm{R}$ mRNA was also upregulated in the prefrontal cortex. These transcripts were chosen for analysis because of their key regulatory role in the mammalian stress system (De Kloet et al, 2005), which we wanted to better understand in the context of mGluR7 ablation. To our knowledge there are no obvious similarities in the transcriptional control region of the chosen genes, which does not exclude the possibility that they might be regulated in a concerted fashion. Interestingly, we find that only GR and $5-\mathrm{HT}_{1 \mathrm{~A}} \mathrm{R}$ transcript levels are altered in mGluR7-deficient mice, which implies a selective effect on the feedback system in the HPA axis. The expression levels of both of these genes have previously been shown to be altered by stress, glucocorticoid and antidepressants (Seckl and Fink, 1992; Lopez et al, 1998; Okugawa et al, 1999; Karandrea et al, 2002; Hugin-Flores et al, 2004). Further, mice with functional downregulation/ablation of these two receptors have altered emotional behaviors relevant to anxiety and depression (Toth, 2003; Urani and Gass, 2003; Boyle et al, 2005). The HPA-axis activity is controlled by a feedback mechanism triggered mainly through the stimulation of GRs located in the cerebral cortex, the hippocampus, and the hypothalamus (Magarinos et al, 1987; Diorio et al, 1993; Feldman and Weidenfeld, 1999; Mizoguchi et al, 2003), and a reduced GR expression and function has been proposed to contribute to HPA-axis alterations in depression (Holsboer and Barden, 1996; Pariante and Miller, 2001; Webster et al, 2002). Further, it is clear that the expression and function of the $5-\mathrm{HT}_{1 \mathrm{~A}} \mathrm{R}$ is regulated by glucocorticoids and GRs (Chalmers et al, 1994; Laaris et al, 1995; Hery et al, 2000; Ou et al, 2001; Andrews et al, 2004; Froger et al, 2004; De Kloet et al, 2005). Taken together these data suggest that there is a selective dysregulation of the integration of the stress response in mGluR7 $7^{-1-}$ mice which is opposite to that seen in some human psychopathological states.

Glutamatergic neurotransmission has long been implicated as a critical regulator of the stress response (van den Pol et al, 1990; Brann, 1995). mGluRs in particular appear to play a crucial role in mediating neuroendocrine responses. Specifically, the nonselective mGluR agonist (1S,3R)-1aminocyclopentane-1,3-dicarboxylate (ACPD), when administered i.c.v., induced a significant increase in plasma corticosterone (Lang and Ajmal, 1995). Whereas, an involvement of group-I and possibly group-II mGluRs has been reported (Johnson et al, 2001; Bradbury et al, 2003; Scaccianoce et al, 2003), it has also been demonstrated that i.c.v. administration of the nonselective group-III mGluR agonists L-AP4 and L-SOP activates the HPA axis (Johnson et al, 2001). Our current data showing both altered corticosterone levels and feedback regulation in $\mathrm{mGluR7}^{-1-}$ mice suggest that mGluR7, at least in part, may modulates the increase in stress hormones induced by group-III mGluR agonists. The mechanism underlying this increase is currently unclear. However, Johnson et al (2001), based on an earlier model of Tasker et al (1998), suggested that as group-III mGluRs regulate the activity of GABA 
interneurones in the hypothalamus (Schrader and Tasker, 1997), agonists, such as L-AP4 and L-SOP, might act by decreasing L-glutamate release from hippocampal-hypothalamic tracts. Thus, there would be a decreased tone driving GABAergic interneurones and a disinhibition on corticotrophin release factor-containing PVN neurons of the hypothalamus. Alternatively, it has been speculated that group-III agonists might be acting directly on presynaptic terminals of the GABAergic interneurones and activate hetereo-autoreceptors and thus group-III mGluR stimulation could directly limit the degree of inhibitory tone that is on the PVN cells (Johnson et al 2001; Tasker et al, 1998). Both scenarios might explain how the absence of mGluR7 leads to a state of neuroendocrine dysfunction as has been seen in the present studies which may subsequently induce an altered response in stress-related behaviors.

It is important to note that there are many brain regions other than the hippocampus and hypothalamus, which contribute to stress-related pathology and future studies should focus on whether mGluR7 plays a role in regulating stress-relevant genes in structures such as the amygdala, lateral septum, cortex, dorsal raphe nucleus, and locus coeruleus. Furthermore, the analysis of the expression of mRNA transcripts in different regions within the hippocampus (eg dentate gyrus, CA1 etc), in addition to the examination of the cellular localization of the observed changes in various brain regions will aid in the understanding, at a circuit level, of the role of mGluR7 in stressrelated pathologies.

To further examine the potential functional consequences of the changes in stress-related genes we assessed baseline and stress-induced concentrations of corticosterone and ACTH in mGluR7 ${ }^{-1-}$ mice. There was a strong trend toward a lower basal corticosterone and ACTH level which suggests that mice lacking mGluR7 function at abnormal homeostatic concentrations of circulating glucocorticoids. However, both genotypes responded equally, in terms of neuroendocrine activation, to swim stress insults which resulted in a marked increase in corticosterone and ACTH levels. It is possible that a ceiling response was observed and that a differential effect could be observed if a less severe stress was employed. However, the rationale for choosing this stressor was based on the fact that mGluR7 ${ }^{-1-}$ mice have an altered behavioral response to this stressor (Cryan et al, 2003). It is interesting to note that in the swim-stress studies the lower basal levels of stress hormones, which we previously observed in a separate cohort of mice, was also detected and at a level that was statistically significant (see Figure 3), thus giving further credence to the initial findings.

To assess whether there is an altered GR-mediated negative feedback we assessed the effects of the synthetic glucocorticoid dexamethasone which at low doses, such as that used here, acts as a GR agonist (Meijer et al, 1998; Cole et al, 2000; Groenink et al, 2002). Mice lacking mGluR7 show a clear hypersensitivity to dexamethasone at the lower dose tested $(0.03 \mathrm{mg} / \mathrm{kg})$. This suggests that there is indeed an altered functional negative feedback of the HPA axis. This enhanced suppression is opposite to that seen in many depressed patients who have a blunted hormonal response to dexamethasone (Holsboer et al, 1980; Carroll, 1982). This correlates well with the antidepressant-like response ob- served in behavioral studies with $\mathrm{mGluR7}^{-1-}$ mice (Cryan et al, 2003). Despite its historical widespread use in clinical settings there are surprisingly few studies employing the dexamethasone suppression test in genetically modified mice (Cryan and Mombereau, 2004). Here we demonstrate that it can be a sensitive marker of HPA-axis dysregulation. Interestingly, although $\mathrm{mGluR7}^{-1-}$ mice have a dysregulated HPA axis, these alterations occur independent of any gross abnormality in adrenal weight with both genotypes having the same relative adrenal weight (Table 1). Increases in relative adrenal weight have been observed following chronic stress (Watanabe et al, 1992) and in major depression (Nemeroff et al, 1992).

We observed an increase in BDNF protein levels in the hippocampus of $\mathrm{mGluR7}^{-1-}$ mice in a reproducible fashion, which also correlates well with the antidepressant-like phenotype observed behaviorally. Intracerebral ventricular or intrahippocampal administration of BDNF has been shown to have an antidepressant-like effect in various animal tests of antidepressant activity (Siuciak et al, 1997; Shirayama et al, 2002; Hoshaw et al, 2005). Furthermore, antidepressant medications have been shown to increase BDNF levels in the hippocampus (Nibuya et al, 1995; De Foubert et al, 2004; Russo-Neustadt et al, 2004; but see Altar et al, 2003; Coppell et al, 2003; Jacobsen and Mork, 2004). Further evidence for a role of BDNF in antidepressant action comes from studies using genetically modified mice with impaired levels of BDNF or its receptor TRK-B, which are resistant to the behavioral effects of antidepressants (Saarelainen et al, 2003). Emerging evidence further suggests that BDNF may play a key role in the pathophysiology of stress-related disorders. Lower hippocampal BDNF levels have been found subsequent to various stressors such as prenatal stress (Fumagalli et al, 2004), footshock stress (Rasmusson et al, 2002), postnatal stress (MacQueen et al, 2003; Roceri et al, 2004) and restraint stress (Smith et al, 1995; Vaidya et al, 1997; Xu et al, 2004). Also of interest is the fact that intrahippocampal administration of BDNF protects against stress-induced impairments in spatial learning and memory and LTP (Radecki et al, 2005). Mechanisms underlying how stress alters BDNF levels and how BDNF modifies behavior are not currently clear (see Tapia-Arancibia et al, 2004 for review). Interestingly, recent studies have shown that BDNF can have direct stimulating effects on the HPA axis suggesting that BDNF could be a stress-responsive intercellular messenger since when it is exogenously administered it acts as an essential factor in the activation and recruitment of hypothalamic CRF neurons (Givalois et al, 2004). However, the effects of chronic BDNF administration are unknown and may confer differential influence on the HPA axis. It is important to note, that the changes in protein levels of BDNF observed in mGluR7 $7^{-l-}$ mice occur independent of detectable changes at the mRNA levels. Reasons for this may in some way be due to the fact that whole tissue homogenate may dilute potential effects at the mRNA levels that occur only in specific subregions of the hippocampus, however this reasoning is unsatisfactory as it should also apply to regulation at the protein level. Moreover, in agreement with our findings, recent studies have also shown very disparate results between BDNF mRNA and protein levels in the same tissue following various antidepressant manipulations 
(De Foubert et al, 2004; Jacobsen and Mork, 2004). The reasons for such differential responses at mRNA and protein level are currently unclear and warrant further investigation and possibly reflect regulation of BDNF at the translational level.

There has been an upsurge in the use of genetically modified mice to assess depression- and anxiety-related phenotypes (Cryan et al, 2002; Cryan and Mombereau, 2004). However, the majority of phenotypic analysis has focused specifically on behavioral readouts, such as immobility in the forced swim test, in isolation of other physiological and molecular biomarkers. Our current data demonstrate the utility of adapting such an approach and exemplify how such analyses can complement behavioral studies. This is perhaps even more important for mice which have genetically modified levels of target proteins, such as in the case of mGluR7, where there are no complimentary pharmacological tools available. However, we cannot rule out that the changes observed here maybe secondary to alterations in other circuits, not yet identified, which are directly influenced by the null mutation of mGluR7. In conclusion, our current data demonstrate that ablation of mGluR7 results in specific changes in key regulators of the $\mathrm{HPA}$ axis, namely $5 \mathrm{HT}_{1 \mathrm{~A}}$ receptors, GR, corticosterone, and in altered BDNF levels, in a direction opposite to that found in human depression or following chronic stress. These changes correlate with the previously identified antistress and antidepressant-like behavioral effects observed in mGluR7 ${ }^{-1-}$ mice. Furthermore, the current data suggest that development of selective mGluR7 ligands may provide a novel strategy for modifying stressrelated disorders.

\section{ACKNOWLEDGEMENTS}

We thank Professor Y-A Barde for providing the BDNF antibodies and Professor P Herrling for giving continuous supports and for critical, very helpful discussions. We also thank H Buerki, Ch Kohler, G Kuntzelmann, and J Richter for their excellent technical assistance. In addition, we thank Dr C Gentsch for providing the adrenal gland weight data (Table 1) and for very helpful discussions. JFC is supported by National Institutes of Mental Health/National Institute on Drug Abuse Grant U01 MH69062.

\section{REFERENCES}

Altar CA, Whitehead RE, Chen R, Wortwein G, Madsen TM (2003). Effects of electroconvulsive seizures and antidepressant drugs on brain-derived neurotrophic factor protein in rat brain. Biol Psychiatr 54: 703-709.

Andrews MH, Kostaki A, Setiawan E, McCabe L, Matthews SG (2004). Developmental regulation of 5-HT1A receptor mRNA in the fetal limbic system: response to antenatal glucocorticoid. Brain Res Dev Brain Res 149: 39-44.

Barden N (2004). Implication of the hypothalamic-pituitaryadrenal axis in the physiopathology of depression. J Psychiatr Neurosci 29: 185-193.

Bergink V, van Megen HJ, Westenberg HG (2004). Glutamate and anxiety. Eur Neuropsychopharmacol 14: 175-183.

Boyle MP, Brewer JA, Funatsu M, Wozniak DF, Tsien JZ, Izumi Y et al (2005). Acquired deficit of forebrain glucocorticoid receptor produces depression-like changes in adrenal axis regulation and behavior. Proc Natl Acad Sci USA 102: 473-478.

Bradbury MJ, Giracello DR, Chapman DF, Holtz G, Schaffhauser H, Rao SP et al (2003). Metabotropic glutamate receptor 5 antagonist-induced stimulation of hypothalamic-pituitary-adrenal axis activity: interaction with serotonergic systems. Neuropharmacology 44: 562-572.

Brann DW (1995). Glutamate: a major excitatory transmitter in neuroendocrine regulation. Neuroendocrinology 61: 213-225.

Bushell TJ, Sansig G, Collett VJ, van der Putten H, Collingridge GL (2002). Altered short-term synaptic plasticity in mice lacking the metabotropic glutamate receptor mGlu7. Sci World J 2: 730-737.

Carroll BJ (1982). The dexamethasone suppression test for melancholia. Br J Psychiatr 140: 292-304.

Castren E (2004). Neurotrophic effects of antidepressant drugs. Curr Opin Pharmacol 4: 58-64.

Chalmers DT, Lopez JF, Vazquez DM, Akil H, Watson SJ (1994). Regulation of hippocampal 5-HT1A receptor gene expression by dexamethasone. Neuropsychopharmacology 10: 215-222.

Cole MA, Kim PJ, Kalman BA, Spencer RL (2000). Dexamethasone suppression of corticosteroid secretion: evaluation of the site of action by receptor measures and functional studies. Psychoneuroendocrinology 25: 151-167.

Coppell AL, Pei Q, Zetterstrom TS (2003). Bi-phasic change in BDNF gene expression following antidepressant drug treatment. Neuropharmacology 44: 903-910.

Cryan JF, Leonard BE (2000). 5-HT1A and beyond: the role of serotonin and its receptors in depression and the antidepressant response. Hum Psychopharmacol 15: 113-135.

Cryan JF, Mombereau C (2004). In search of a depressed mouse: utility of models for studying depression-related behavior in genetically modified mice. Mol Psychiatr 9: 326-357.

Cryan JF, Kelly PH, Neijt HC, Sansig G, Flor PJ, van Der Putten H (2003). Antidepressant and anxiolytic-like effects in mice lacking the group III metabotropic glutamate receptor mGluR7. Eur J Neurosci 17: 2409-2417.

Cryan JF, Markou A, Lucki I (2002). Assessing antidepressant activity in rodents: recent developments and future needs. Trends Pharmacol Sci 23: 238-245.

De Foubert G, Carney SL, Robinson CS, Destexhe EJ, Tomlinson R, Hicks CA et al (2004). Fluoxetine-induced change in rat brain expression of brain-derived neurotrophic factor varies depending on length of treatment. Neuroscience 128: 597-604.

De Kloet ER, Joels M, Holsboer F (2005). Stress and the brain: from adaptation to disease. Nat Rev Neurosci 6: 463-475.

De Kloet ER, Vreugdenhil E, Oitzl MS, Joels M (1998). Brain corticosteroid receptor balance in health and disease. Endocr Rev 19: 269-301.

Diorio D, Viau V, Meaney MJ (1993). The role of the medial prefrontal cortex (cingulate gyrus) in the regulation of hypothalamic-pituitary-adrenal responses to stress. J Neurosci 13: 3839-3847.

Duman RS (2002). Pathophysiology of depression: the concept of synaptic plasticity. Eur Psychiatr 17(Suppl 3): 306-310.

Feldman S, Weidenfeld J (1999). Glucocorticoid receptor antagonists in the hippocampus modify the negative feedback following neural stimuli. Brain Res 821: 33-37.

Flor PJ, Van Der Putten H, Ruegg D, Lukic S, Leonhardt T, Bence $M$ et al (1997). A novel splice variant of a metabotropic glutamate receptor, human mGluR7b. Neuropharmacology 36: 153-159.

Froger N, Palazzo E, Boni C, Hanoun N, Saurini F, Joubert C et al (2004). Neurochemical and behavioral alterations in glucocorticoid receptor-impaired transgenic mice after chronic mild stress. J Neurosci 24: 2787-2796.

Fumagalli F, Bedogni F, Perez J, Racagni G, Riva MA (2004). Corticostriatal brain-derived neurotrophic factor dysregulation 
in adult rats following prenatal stress. Eur J Neurosci 20: $1348-1354$.

Givalois L, Naert G, Rage F, Ixart G, Arancibia S, Tapia-Arancibia L (2004). A single brain-derived neurotrophic factor injection modifies hypothalamo-pituitary-adrenocortical axis activity in adult male rats. Mol Cell Neurosci 27: 280-295.

Groenink L, Dirks A, Verdouw PM, Schipholt M, Veening JG, van der Gugten J et al (2002). HPA axis dysregulation in mice overexpressing corticotropin releasing hormone. Biol Psychiatr 51: 875-881.

Hashimoto K, Shimizu E, Iyo M (2004). Critical role of brainderived neurotrophic factor in mood disorders. Brain Res Brain Res Rev 45: 104-114.

Hery M, Semont A, Fache MP, Faudon M, Hery F (2000). The effects of serotonin on glucocorticoid receptor binding in rat raphe nuclei and hippocampal cells in culture. J Neurochem 74: 406-413.

Holsboer F (2000). The corticosteroid receptor hypothesis of depression. Neuropsychopharmacology 23: 477-501.

Holsboer F, Barden N (1996). Antidepressants and hypothalamic-pituitary-adrenocortical regulation. Endocr Rev 17: 187-205.

Holsboer F, Bender W, Benkert O, Klein HE, Schmauss M (1980). Diagnostic value of dexamethasone suppression test in depression. Lancet 2: 706 .

Hoshaw BA, Malberg JE, Lucki I (2005). Central administration of IGF-I and BDNF leads to long-lasting antidepressant-like effects. Brain Res 1037: 204-208.

Hugin-Flores ME, Steimer T, Aubert ML, Schulz P (2004). Mineralo- and glucocorticoid receptor mrnas are differently regulated by corticosterone in the rat hippocampus and anterior pituitary. Neuroendocrinology 79: 174-184.

Jacobsen JP, Mork A (2004). The effect of escitalopram, desipramine, electroconvulsive seizures and lithium on brainderived neurotrophic factor mRNA and protein expression in the rat brain and the correlation to 5-HT and 5-HIAA levels. Brain Res 1024: 183-192.

Jacobson L, Sapolsky R (1991). The role of the hippocampus in feedback regulation of the hypothalamic-pituitary-adrenocortical axis. Endocr Rev 12: 118-134.

Johnson MP, Kelly G, Chamberlain M (2001). Changes in rat serum corticosterone after treatment with metabotropic glutamate receptor agonists or antagonists. J Neuroendocrinol 13: 670-677.

Karandrea D, Kittas C, Kitraki E (2002). Forced swimming differentially affects male and female brain corticosteroid receptors. Neuroendocrinology 75: 217-226.

Kinoshita A, Shigemoto R, Ohishi H, van der Putten H, Mizuno N (1998). Immunohistochemical localization of metabotropic glutamate receptors, mGluR7a and mGluR7b, in the central nervous system of the adult rat and mouse: a light and electron microscopic study. J Comp Neurol 393: 332-352.

Kolbeck R, Bartke I, Eberle W, Barde YA (1999). Brain-derived neurotrophic factor levels in the nervous system of wild-type and neurotrophin gene mutant mice. $J$ Neurochem 72: 1930-1938.

Krystal JH, Sanacora G, Blumberg H, Anand A, Charney DS, Marek $\mathrm{G}$ et al (2002). Glutamate and GABA systems as targets for novel antidepressant and mood-stabilizing treatments. Mol Psychiatr 7(Suppl 1): S71-S80.

Laaris N, Haj-Dahmane S, Hamon M, Lanfumey L (1995). Glucocorticoid receptor-mediated inhibition by corticosterone of 5-HT1A autoreceptor functioning in the rat dorsal raphe nucleus. Neuropharmacology 34: 1201-1210.

Lang CH, Ajmal M (1995). Metabolic, hormonal, and hemodynamic changes inducced by metabotropic excitatory amino acid agonist (1S, 3R)-ACPD. Am J Physiol 268: R1026-R1033.

Leitch $\mathrm{MM}$, Ingram $\mathrm{CD}$, Young $\mathrm{AH}, \mathrm{McQuade} \mathrm{R}$, Gartside SE (2003). Flattening the corticosterone rhythm attenuates 5-HT1A autoreceptor function in the rat: relevance for depression. Neuropsychopharmacology 28: 119-125.

Linden AM, Johnson BG, Peters SC, Shannon HE, Tian M, Wang Y et al (2002). Increased anxiety-related behavior in mice deficient for metabotropic glutamate 8 (mGlu8) receptor. Neuropharmacology 43: 251-259.

Livak KJ, Schmittgen TD (2001). Analysis of relative gene expression data using real-time quantitative PCR and the 2(-Delta Delta C(T)) Method. Methods 25: 402-408.

Lopez JF, Chalmers DT, Little KY, Watson SJ (1998). A.E. Bennett Research Award. Regulation of serotonin1A, glucocorticoid, and mineralocorticoid receptor in rat and human hippocampus: implications for the neurobiology of depression. Biol Psychiatr 43: 547-573.

MacQueen GM, Ramakrishnan K, Ratnasingan R, Chen B, Young LT (2003). Desipramine treatment reduces the long-term behavioural and neurochemical sequelae of early-life maternal separation. Int J Neuropsychopharmacol 6: 391-396.

Magarinos AM, Somoza G, De Nicola AF (1987). Glucocorticoid negative feedback and glucocorticoid receptors after hippocampectomy in rats. Horm Metab Res 19: 105-109.

Makoff A, Pilling C, Harrington K, Emson P (1996). Human metabotropic glutamate receptor type 7: molecular cloning and mRNA distribution in the CNS. Brain Res Mol Brain Res 40: 165-170.

Masugi M, Yokoi M, Shigemoto R, Muguruma K, Watanabe Y, Sansig G et al (1999). Metabotropic glutamate receptor subtype 7 ablation causes deficit in fear response and conditioned taste aversion. J Neurosci 19: 955-963.

Meijer OC, de Lange EC, Breimer DD, de Boer AG, Workel JO, de Kloet ER (1998). Penetration of dexamethasone into brain glucocorticoid targets is enhanced in mdr1A P-glycoprotein knockout mice. Endocrinology 139: 1789-1793.

Mizoguchi K, Ishige A, Aburada M, Tabira T (2003). Chronic stress attenuates glucocorticoid negative feedback: involvement of the prefrontal cortex and hippocampus. Neuroscience 119: 887-897.

Nemeroff CB, Krishnan KR, Reed D, Leder R, Beam C, Dunnick NR (1992). Adrenal gland enlargement in major depression. A computed tomographic study. Arch Gen Psychiatry 49: 384-387.

Nibuya M, Morinobu S, Duman RS (1995). Regulation of BDNF and trkB mRNA in rat brain by chronic electroconvulsive seizure and antidepressant drug treatments. J Neurosci 15: 7539-7547.

Okugawa G, Omori K, Suzukawa J, Fujiseki Y, Kinoshita T, Inagaki C (1999). Long-term treatment with antidepressants increases glucocorticoid receptor binding and gene expression in cultured rat hippocampal neurones. J Neuroendocrinol 11: 887-895.

Ou XM, Storring JM, Kushwaha N, Albert PR (2001). Heterodimerization of mineralocorticoid and glucocorticoid receptors at a novel negative response element of the 5-HT1A receptor gene. J Biol Chem 276: 14299-14307.

Pariante CM, Miller AH (2001). Glucocorticoid receptors in major depression: relevance to pathophysiology and treatment. Biol Psychiatr 49: 391-404.

Paul IA, Skolnick P (2003). Glutamate and depression: clinical and preclinical studies. Ann NY Acad Sci 1003: 250-272.

Plotsky PM, Owens MJ, Nemeroff CB (1998). Psychoneuroendocrinology of depression. Hypothalamic-pituitary-adrenal axis. Psychiatr Clin North Am 21: 293-307.

Porter RJ, Gallagher P, Watson S, Young AH (2004). Corticosteroid-serotonin interactions in depression: a review of the human evidence. Psychopharmacology (Berlin) 173: 1-17.

Posener JA, DeBattista C, Williams GH, Chmura Kraemer H, Kalehzan BM, Schatzberg AF (2000). 24-Hour monitoring of cortisol and corticotropin secretion in psychotic and 
nonpsychotic major depression. Arch Gen Psychiatr 57: 755-760.

Radecki DT, Brown LM, Martinez J, Teyler TJ (2005). BDNF protects against stress-induced impairments in spatial learning and memory and LTP. Hippocampus 15: 246-253.

Rasmusson AM, Shi L, Duman R (2002). Downregulation of BDNF mRNA in the hippocampal dentate gyrus after re-exposure to cues previously associated with footshock. Neuropsychopharmacology 27: 133-142.

Roceri M, Cirulli F, Pessina C, Peretto P, Racagni G, Riva MA (2004). Postnatal repeated maternal deprivation produces age-dependent changes of brain-derived neurotrophic factor expression in selected rat brain regions. Biol Psychiatry 55: 708-714.

Russo-Neustadt AA, Alejandre H, Garcia C, Ivy AS, Chen MJ (2004). Hippocampal brain-derived neurotrophic factor expression following treatment with reboxetine, citalopram, and physical exercise. Neuropsychopharmacology 29: 2189-2199.

Saarelainen T, Hendolin P, Lucas G, Koponen E, Sairanen M, MacDonald E et al (2003). Activation of the TrkB neurotrophin receptor is induced by antidepressant drugs and is required for antidepressant-induced behavioral effects. J Neurosci 23: 349-357.

Sansig G, Bushell TJ, Clarke VR, Rozov A, Burnashev N, Portet C et al (2001). Increased seizure susceptibility in mice lacking metabotropic glutamate receptor 7. J Neurosci 21: 8734-8745.

Scaccianoce S, Matrisciano F, Del Bianco P, Caricasole A, Di Giorgi Gerevini V, Cappuccio I et al (2003). Endogenous activation of group-II metabotropic glutamate receptors inhibits the hypothalamic-pituitary-adrenocortical axis. Neuropharmacology 44: 555-561.

Schrader LA, Tasker JG (1997). Presynaptic modulation by metabotropic glutamate receptors of excitatory and inhibitory synaptic inputs to hypothalamic magnocellular neurons. J Neurophysiol 77: 527-536.

Seckl JR, Fink G (1992). Antidepressants increase glucocorticoid and mineralocorticoid receptor mRNA expression in rat hippocampus in vivo. Neuroendocrinology 55: 621-626.

Shirayama Y, Chen AC, Nakagawa S, Russell DS, Duman RS (2002). Brain-derived neurotrophic factor produces antidepressant effects in behavioral models of depression. J Neurosci 22: 3251-3261.

Siuciak JA, Lewis DR, Wiegand SJ, Lindsay RM (1997). Antidepressant-like effect of brain-derived neurotrophic factor (BDNF). Pharmacol Biochem Behav 56: 131-137.
Smith MA, Makino S, Kvetnansky R, Post RM (1995). Stress and glucocorticoids affect the expression of brain-derived neurotrophic factor and neurotrophin-3 mRNAs in the hippocampus. J Neurosci 15: 1768-1777.

Steckler T, Holsboer F, Reul JM (1999). Glucocorticoids and depression. Baillieres Best Pract Res Clin Endocrinol Metab 13: 597-614.

Swanson CJ, Bures M, Johnson MP, Linden AM, Monn JA, Schoepp DD (2005). Metabotropic glutamate receptors as novel targets for anxiety and stress disorders. Nat Rev Drug Discov 4: 131-144.

Tapia-Arancibia L, Rage F, Givalois L, Arancibia S (2004). Physiology of BDNF: focus on hypothalamic function. Front Neuroendocrinol 25: 77-107.

Tasker JG, Boudaba C, Schrader LA (1998). Local glutamatergic and gabaergic synaptic circuits and metabotropic glutamate receptors in the hypothalamic paraventricular and supraoptic nuclei. Adv Exp Med Biol 449: 117-121.

Toth M (2003). 5-HT1A receptor knockout mouse as a genetic model of anxiety. Eur J Pharmacol 463: 177-184.

Urani A, Gass P (2003). Corticosteroid receptor transgenic mice: models for depression? Ann NY Acad Sci 1007: 379-393.

Vaidya VA, Marek GJ, Aghajanian GK, Duman RS (1997). 5-HT2A receptor-mediated regulation of brain-derived neurotrophic factor mRNA in the hippocampus and the neocortex. J Neurosci 17: 2785-2795.

van den Pol AN, Wuarin J-P, Dudek FE (1990). Glutamate, the dominant excitatory transmitter in neuroendocrine regulation. Science 250: 1276-1278.

Watanabe Y, Gould E, Daniels DC, Cameron H, McEwen BS (1992). Tianeptine attenuates stress-induced morphological changes in the hippocampus. Eur J Pharmacol 222: 157-162.

Webster MJ, Knable MB, O'Grady J, Orthmann J, Weickert CS (2002). Regional specificity of brain glucocorticoid receptor mRNA alterations in subjects with schizophrenia and mood disorders. Mol Psychiatr 7: 985-994, 924.

Wong ML, Licinio J (2001). Research and treatment approaches to depression. Nat Rev Neurosci 2: 343-351.

Wong ML, Licinio J (2004). From monoamines to genomic targets: a paradigm shift for drug discovery in depression. Nat Rev Drug Discov 3: 136-151.

$\mathrm{Xu} \mathrm{H}$, Luo C, Richardson JS, Li XM (2004). Recovery of hippocampal cell proliferation and BDNF levels, both of which are reduced by repeated restraint stress, is accelerated by chronic venlafaxine. Pharmacogenomics J 4: 322-331. 